\title{
Kernos
}

Revue internationale et pluridisciplinaire de religion grecque antique

$31 \mid 2018$

Varia

\section{Inner Purity \& Pollution in Greek Religion. Volume 1: Early Greek Religion}

\section{Saskia Peels-Matthey}

\section{(2) OpenEdition \\ Journals}

\section{Electronic version}

URL: http://journals.openedition.org/kernos/2778

DOI: 10.4000/kernos.2778

ISSN: 2034-7871

\section{Publisher}

Centre international d'étude de la religion grecque antique

\section{Printed version}

Date of publication: 1 December 2018

Number of pages: 299-302

ISBN: 978-2-87562-055-2

ISSN: 0776-3824

\section{Electronic reference}

Saskia Peels-Matthey, "Inner Purity \& Pollution in Greek Religion. Volume 1: Early Greek Religion", Kernos [Online], 31 | 2018, Online since 01 October 2018, connection on 25 January 2021. URL: http:// journals.openedition.org/kernos/2778 ; DOI: https://doi.org/10.4000/kernos.2778

This text was automatically generated on 25 January 2021.

Kernos 


\title{
Inner Purity \& Pollution in Greek Religion. Volume 1: Early Greek Religion
}

\author{
Saskia Peels-Matthey
}

\section{REFERENCES}

Andrej PETROVIC, Ivana PETROVIC, Inner Purity \& Pollution in Greek Religion. Volume 1: Early Greek Religion, Oxford, Oxford University Press, 2016. 1 vol. 15,8 × $24 \mathrm{~cm}$, xvi+337 p.

ISBN : 978-0-19-876804-3.

1 This monograph traces the concept of 'inner purity' through time. Its main argument is that, when approaching gods and engaging in rituals, a worshipper's inner stance, i.e. his attitudes and thoughts, rather than just the outward correctness of the ritual performance, are what matters. The correct inner stance of the worshipper was often formulated in Greek literature in terms of purity of mind, soul and thoughts ('the "purity" of psychic or noetic organs or processes', p. 5). Crucially, this concept of inner purity 'possessed a moral dimension', which was a pivotal aspect of the Greek purity doctrine (p. 8). Inner purity was 'an integral part of the Greek notion of piety and an elementary prerequisite for successful interaction with the gods' (p. 4).

While previous scholars, such as Parker, Chaniotis and others ${ }^{1}$ have traced the 'emergence and subsequent development of the moral aspect of Greek purity beliefs' (= inner purity), A. and I. Petrovic (A.I.P.) argue that such a concept was there from the beginning: 'it was an element of the purity system which is as old as our earliest attestations of the system itself' (p. 25).

3 In their investigation, A.I.P. also wish to shed light on the ever-elusive notion of ancient Greek 'belief'. This is possible, in their view, because worshippers' inner purity contained a reflective element: 'inner purity as a category ... is often associated with the acceptance of and compliance with specific ethical and religious values, especially 
morality, righteousness and justice, and it can also pertain to the recognition of the specific nature and powers of individual divinities, or to contemplation on the significance of ritual action' (p. 5).

4 A.I.P. provide a survey of textual evidence for their hypotheses, close-reading the relevant passages and discussing them in their broader textual and cultural contexts. The approach is both diachronic and synchronic (focusing in most cases on one author per chapter, and then ordering the chapters chronologically, A.I.P. are able to study how the concept changes, but are also sensitive to the coexistence of different 'subsystems'). A.I.P. have chosen for a narrow focus, restricting their discussion only to passages 'which explicitly deal with the inner states of ritual performers' (p. 36). Even so, the sheer amount of relevant passages has led them to opt for a division of the material into two volumes: the first (present) volume dealing with the evidence until the early fourth century, and the second (still under construction) treating the material from Plato to Iamblichus (a motivation of the chronological cut-off point is found at p. 9-10).

5 After the Introduction, the main body of text is divided into five book-parts and twelve chapters, respectively treating epic (Hesiod), pre-Platonic philosophy (Pythagoras; Heraclitus; Empedocles), literature in a sympotic setting (Xenophanes; the Theognidea), drama (Aeschylus; Sophocles; Euripides; Aristophanes), and the evidence of the 'Orphic' gold leaves. The presentation of the argument in these chapters is crystal clear. Each chapter is preceded by a detailed summary of its main points. All passages are accompanied by translations; A.I.P. are sensitive to specific syntactic or semantic interpretative problems where they occur and explain them succinctly with insightful clarity. Helpful overviews of, and pointers to previous scholarship on difficult topics and complex texts are provided. The conclusion contains, among other things, a tabular overview of the relevant Greek passages per chapter. A glossary, defining the main Greek lexemes involved, informs those who are less familiar with the semantic fields of piety, purity and pollution. ${ }^{2}$ Finally, there is a helpful index locorum and an index nominum et rerum. In these ways, A.I.P. show precisely what evidence they have, how they build their argument, and where they stand in respect to previous scholarship. Given the richness of the argument in each chapter, this book would merit a review article. In a brief review such as this one, I will restrict myself to responding to a few selected aspects of the argument.

6 My first point concerns Hesiod. A.I.P.'s main contention, that the idea of purity of the mind can be traced back as far as Hesiod, is presented as resting primarily on one Hesiodic passage about a ritualistic river crossing. This passage is rather difficult to

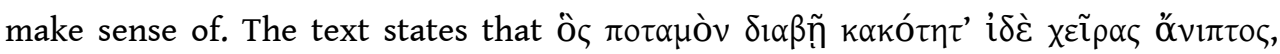
'whoever should cross the river, unwashed with respect to badness and hands' (the gods resent him afterwards and give him trouble). ${ }^{3}$ A.I.P. interpret this as a zeugma

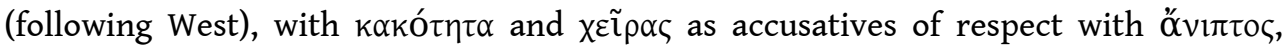
respectively taken metaphorically and literally. Their discussion is excellent, and this is probably the best possible textual solution. But it is still unsatisfactory, since it does not make much sense. 'Impure hands' works fine, but 'unwashed with respect to badness' seems awkward and pleonastic. A.I.P.'s main point about the Works and Days

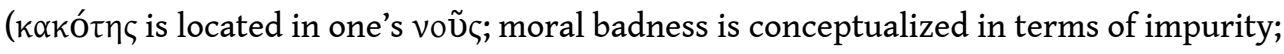
with an impure mind, one cannot successfully perform a ritual) is convincingly argued, but it is unfortunate that such a pivotal passage should be so awkward semantically. 
7 A second passage, discussed in the same chapter on p. 45 and p. 47, might perhaps be promoted to the status of primary evidence. Perses is reminded that Zeus passes judgment on 'those for whom bad transgression and wicked deeds are an object of

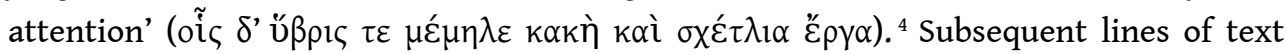
explain in more detail to Perses what sorts of transgressions may be envisaged and what happens to sinners. But all of this is then contrasted with the injunction to Perses

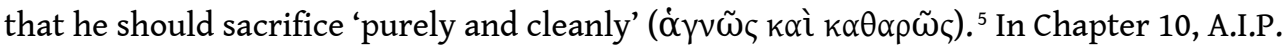
argue about another passage that it 'establishes a diametrical opposition between the

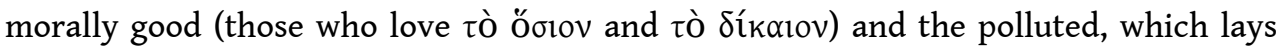
bare that those who are morally good are perceived as pure' (p. 233). The same reasoning, but in the opposite direction may be relevant to the Hesiodic passage: the contrast between the morally dubious (for whom bad úßpı is an object of thought) and those who sacrifice cleanly and purely, implies that a bad attitude is perceived as impure.

8 That the tragedians used, and played with the notions of inner purity and pollution is presented in a way that is completely convincing. A.I.P.'s discussions of well-known passages provide a new and fascinating view on this material. Still, it would be interesting to learn A.I.P.'s view on the status of some of the presented passages as evidence. For example, in a passage in Aeschylus' Suppliants, the Aegyptids are accused

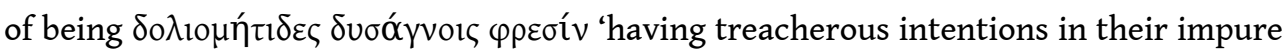
minds' ${ }^{6}$ As A.I.P. explain, this passage contains various (probable) coinages. Before and after this accusation, the Danaids throw out an avalanche of existing or novel religious

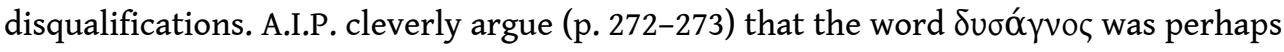
coined by Aeschylus (as opposed to existing óvó́yvoৎ), to refer to the Aegyptids' wrongful attitude towards purity, rather than an absence of purity, since they lack respect for ritual altogether. So, the accusation of inner pollution is there, but in an unexpected way, and it occurs in a rather marked poetical context full of lexical inventions. Does that matter, and if so, how? ${ }^{7}$ A similar question arises from the discussion of Phaedra's famous utterance in Euripides' Hippolytus (discussed on p. 202). When Phaedra claims that her mind has some pollution, the nurse's response is remarkable, since it points to an apparent failure to understand what Phaedra means:

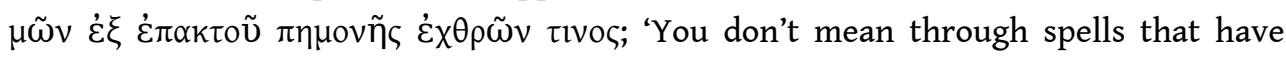
harmed you, from one of your enemies, do you?'s In other words, the nurse wonders whether her mistress refers to sorcery, ${ }^{9}$ but is ready to reject the hypothesis (cf. the particle $\mu \tilde{\omega} v)$. Is it relevant that the internal interlocutor is presented as not readily grasping the idea of a 'polluted mind'? Or is it not?

9 A final point concerns the notion of 'embodied cognition'. A.I.P. explain this notion on p. 205 in some detail, suggesting that it could help us understand one particular dramatic passage. Embodied cognition means that humans understand experiences of an abstract nature (metaphysical, emotional, moral concepts) in terms of experiences of the body. Describing moral behaviour as if it were akin to cleanliness and purity is, therefore, more than a figure of speech; humans actually grasp and experience moral virtue as if it were akin to physical cleanliness. ${ }^{10}$ A.I.P. quote modern, experimental studies which demonstrate that point. In my view, this notion of embodied cognition is actually relevant to the book as a whole, and employing it more broadly in the context of their discussion could provide a strong argument for their main point. If the understanding of moral thought, attitudes and mindsets in terms of mental purity is in 
fact part and parcel of human cognition, then that explains why, and proves incontestably that such thinking can be indeed found from the dawn of Greek literature. Moreover, incorporating this view would, to some extent, make the question of whether inner purity and pollution are metaphorical or not (as discussed on p. 288291) superfluous, since one could argue instead that humans essentially conceptualize the metaphysical concept of 'morality' in terms of purity.

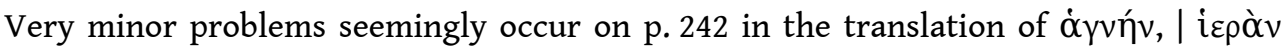

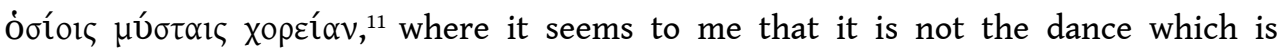
qualified as hosios, 'religiously correct', but rather the initiates; and on p. 66 and in the Conclusion, where the correct transcription of the Greek relating to the 'soul pursuing purity' seems to be psyche hagneuousa, corresponding to the original text quoted on p. 55, instead of psyche hagneusa.

11 Tracing an ancient concept in the textual sources is difficult and energy-consuming, for one cannot easily get to the relevant passages by performing lexical TLG searches. This makes such a study highly valuable for colleagues in the field. In this case, given that most scholars today do not even acknowledge the existence of the concept of 'inner purity' in early Greek literature, or its relevance to the notion of piety and ritual performance, this specific treatment of the archaic and early classical passages is truly new, and as a whole, entirely convincing.

\section{NOTES}

1. R. PARKER, Miasma: Pollution and Purification in Early Greek Religion, Oxford,1996 [1983], p. 322-327; A. CHANIOTIS, "Reinheit des Körpers - Reinheit des Sinnes in den griechischen Kultgesetzen," in J. ASSMANN and Th. SUNDERMEIER (eds.), Schuld, Gewissen und Person, Gütersloh, 1997, p. 142-79; A. CHANIOTIS, "Greek ritual purity: From Automatisms to Moral Distinctions," in P. ROESCH and U. SIMON (eds.), How Purity is Made, Wiesbaden, 2012, p. 123-139.

2. A.I.P. follow Mikalson's translation (J.D. MIKALSON, Ancient Greek Religion, Chichester, $2010^{2}$

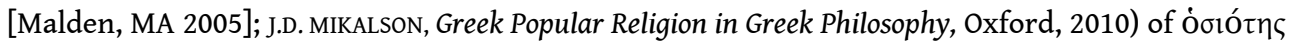
as 'religious correctness' and point out that Mikalson is omitted from my own discussion of this term (S. PEELS, HOSIOS. A Semantic Study of Greek Piety, Mnemosyne Supplement 387, Leiden, 2016). In the published version of my book (A.I.P. saw the earlier doctoral dissertation), I have treated Mikalson's interpretation in some detail (e.g. p. 6-8, 9, 70-71, 83-84). My own interpretation of

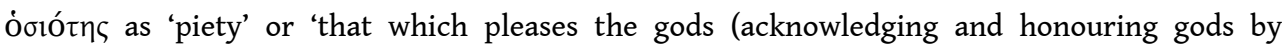
respecting ritual norms and upholding specific ethical values that matter to gods)', would, I suggest, actually fit well into the argument of A.I.P., given their emphasis on piety being based on attitudes and compliance with religious and divinely sanctioned social norms, rather than 'correctness' of actions of worshippers. I argue that 'religious correctness' is only part of the semantic range of öбıৎ.

3. Hesiod, Works and Days, 740-741.

4. Hesiod, Works and Days, 238. Cp. verse 531, where the same verb is used with an explicit

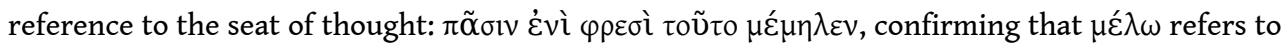
a mental process in this text. 
5. Hesiod, Works and Days, 336-337.

6. Aeschylus, Suppliants, 750-751.

7. In the brief chapter on Aristophanes, A.I.P. convincingly argue that the ban of anyone whose 'thoughts are not clean' (in Aristophanes, Frogs, 355) is part of a parody of a prorrhesis of the Eleusinian Mysteries; and also, that it is a comic play on the frequent emphasis in tragedy that purity of mind is necessary for successful communication with gods. Making jokes about a concept, in the context of a mass media performance, seems the ultimate proof that that concept is firmly established. As such, the chapter on comedy is in my view particularly strong. Is the Aeschylean passage similar, twisting a more 'established' notion of an impure mind (and thus showing it is well-established)? Or conversely, is the notion of an 'impure mind' part of the 'new' inventions in this passage?

8. Euripides, Hippolytus, 317-318.

9. Parker, o.c. (n. 1), p. 222.

10. Cf. G. LAKOFF \& M. JOHNSON, Metaphors we live by, Chicago, 1980; G. LAKOFF \& M. JOHnSON, Philosophy in the Flesh: The Embodied Mind and its Challenge to Western Thought, New York, 1999.

11. Aristophanes, Frogs, 334-5.

\section{AUTHORS}

\section{SASKIA PEELS-MATTHEY}

University of Groningen 